\title{
甘藷蒸切干し製造における中白の発生防止と マルトース生成制御
}

\author{
前波清隆 ${ }^{\S}$, 石谷孝佑*，佐藤 瀏** \\ 静岡県静岡工業技術センター \\ *中国農業科学院日中農業技術研究開発センター \\ ** 岩手大学工学部応用化学科
}

\section{Prevention of White Spot Generation and Control of Maltose Formation in the Processing of Steamed Sweet Potato}

\author{
Kiyotaka Maenami ${ }^{\S}$, Takasuke Ishitani* and Ryu Sato** \\ Shizuoka Industrial Research Institute of Shizuoka Prefecture, \\ 2078 Makigaya Shizuoka City 421-1298 \\ *Japan-China Research and Development Center for Agricultural Technology, \\ 12 Zhongguancun-Nandojie, Haidianqu, Beijing, P.R. China 100081 \\ ** Faculty of Engineering, Iwate University, 4-3-5 Ueda Morioka City 020-8551
}

\begin{abstract}
Steamed and dried sweet potato is one of the Japanese traditional foods. Since the import of sweet potato products is increasing recently, the quality improvement of steamed and dried sweet potato is required. In recent years, the phenomenon that the central part of the steamed sweet potato becomes white in the manufacturing process of steamed and dried sweet potato came to be seen. In order to solve this problem, two experiments were carried out in the real manufacturing process of steamed and dried sweet potato. When the steam pressure of boiler was raised to $1.1 \mathrm{kgf} / \mathrm{cm}^{2}$ from a general level of $0.8 \mathrm{~kg} / \mathrm{cm}^{2}$, the white spots of steamed sweet potato disappeared within a shorter time. Moreover, under the pressure of general level of $0.8 \mathrm{kgf} / \mathrm{cm}^{2}$, by letting sweet potatoes pass through hot water of an iron pot, generating of white spots were able to be prevented and steaming time was apparently shortened. Furthermore, by raising slowly steaming temperature and heating it enough, hydrolysis of sweet potato starch was promoted and retrogradation of the starch was prevented. Based on these numerical analyses, the control technology of steaming which could manufacture the sweet and soft product of excellent in quality was developed. It depended for the manufacturing process of steamed and dried sweet potato on the traditional experiences until now. These results were able to show technologies numerically and it was able to use for preventing of white spots generation. Based on these research results, the processing technology of high value-added of steamed and dried sweet potato was developed.

(Received Aug. 25, 2004 ; Accepted Jan. 25, 2005)
\end{abstract}

甘藷蒸切干しは, 静岡県, 茨城県などで作られている伝 統食品の一つであるが, その製造過程で, 蒸し工程を経て 屯芋の中心部分が白く残る“なかじろ”（茨城県では「しろ た」と言われる。以下，中白とする。）と言う現象がある. 中白の発生は, 夏場に雨が少なく気温が高い場合に多く 発生することが経験的に知られている.

この中白は, 乾燥後むそのまま白く硬くなって残るため 商品価值を大きく損なう。中白の発生は, 場合によっては

テ421-1298 静岡県静岡市牧ヶ谷 2078 番地

* 个100081 中国北京市海淀区中関村南大街 12 号

** T020-8551 岩手県盛岡市上田 4-3-5

$\S$ 連絡先 (Corresponding author),wbs30962@mail.wbs.ne.jp
製造ロット全体の 2 3 割にも及ぶことから蒸切干し製造 に大きな障害となっている. また, 輸入品が増加する中で, 品質のさらなる向上を進める上での大きな課題であある.

中白は，薪で釜の湯を沸かして芋を蒸していた時には殆 んど発生せず，ボイラーを導入するようになってから多く 発生するようになったと言われている，中白が発生する と, 中心部の澱粉の糊化が進まないだけでなく，アミラー ゼによる糖化も進まない, 経験的には, 中白の発生を減ら すため, 蒸気発生量の増加や蒸し時間の延長, 蒸器上部へ の湯の散布などが行われているが，蒸し条件と中白発生の 関係については，いまだ解明されていない. そこで, 本論文では, 蒸し工程を大幅に改善して中白の 


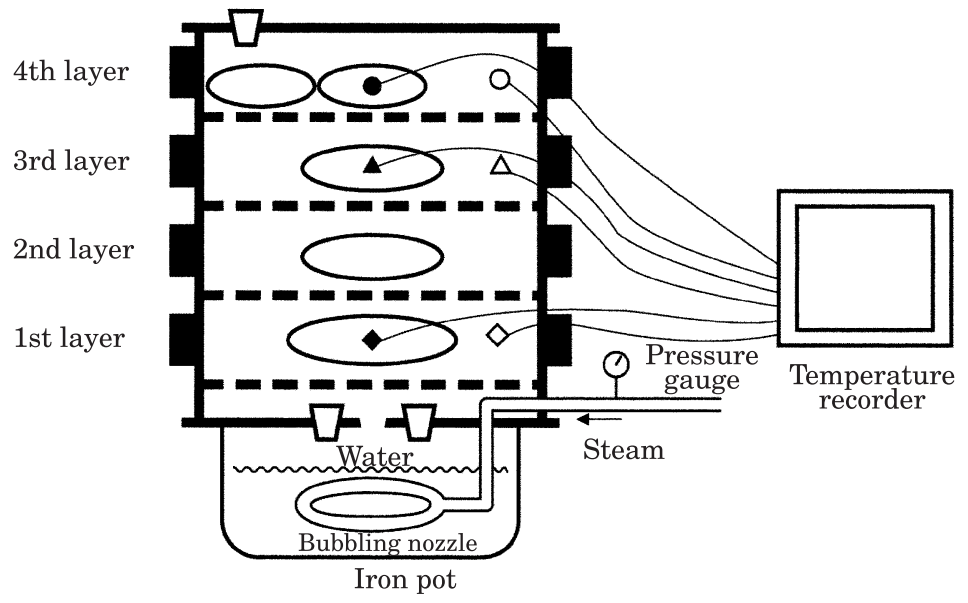

Fig. 1 The steamer used for steaming sweet potato

The size of wooden steamer is $100 \times 100 \times 25(\mathrm{~cm})$, and it can be filled up with sweet potato tubers of $110 \sim 120 \mathrm{~kg}$.

問題を解決し, 蒸し条件を制御することにより甘藷中に含 まれるアミラーゼをより長時間澱粉に作用するようにし， マルトースを多く生成させて甘味を増加させる方法につい て検討した。

\section{実 験 方 法}

\section{1. 供試材料}

(1) 原 料

静岡県小笠郡大東町の砂質土壤に泉 13 号の甘藷苗を 5 月下旬に定植し，塊根を 10 月下旬に収穫して約 1 力月土 中で貯蔵したものを用いた. 泉 13 号の特徵は, 肉質が黄色 で塊根重量が 300 900 g の長紡錘形1) の大型種である. 試 料は，慣行法に準じ，格子の目を $6,8,10 \mathrm{~cm}$ の 3 段階に したロータリー式円筒篩機で，400 g 区 (380〜490 g)，600 $\mathrm{g}$ 区 $(500 \sim 740 \mathrm{~g}) ， 800 \mathrm{~g}$ 区 $(750 \sim 900 \mathrm{~g})$ に分別した.

\section{(2) 蒸 器}

蒸器の構造を Fig. 1 に示した. 最下部の円形平底の鉄釜 （直径 $90 \mathrm{~cm}$, 深さ $40 \mathrm{~cm}$ ) は熱水中に蒸気を吹き込む散気 管を備えている. 直経 $5 \mathrm{~cm}$ の蒸気孔がある縦横 $120 \mathrm{~cm}$ の 正方形の平らな蓋（鬼板と呼ぶ，材の厚さ $6 \mathrm{~cm}$ ) を釜の上 に置き, 次いで縦横 $100 \mathrm{~cm}$, 高さ $15 \mathrm{~cm}$ の木枠を置く. そ の上に縦横 $100 \mathrm{~cm}$, 深さ $25 \mathrm{~cm}$ の木製（厚さ $4 \mathrm{~cm}$ ) で底が 竹製のスノコになっている箱形の木枠を置き，これに塊根 （以下，芋という） 110～120 kg を充填する，通常，木枠は 4 段に重ね，一度に $450 \mathrm{~kg}$ の芋を蒸す。最上部には $5 \mathrm{~cm}$ 径の観察栓のある縦横 $120 \mathrm{~cm}$ の正方形の木製の蓋（厚さ $6 \mathrm{~cm}$ ) をする.

蒸器への蒸気は, ボイラー（(株）カッザワ製, 蒸気発生 量 $140000 \mathrm{kcal} / \mathrm{h}$, 電熱面積 $3.42 \mathrm{~m}^{2}$ ) で生成した. 直接蒸気 を導入する方式では鉄釜に湯を入れず，湯通し蒸気の場合 には鉄釜に湯を入れ，この湯を通した蒸気で蒸した。木 枠・鬼板・釜の接合部には濡れた帯布を挟み蒸気の漏れを
防止した。

\section{2. 中白発生条件の検討}

(1) 蒸気の導入方式の違いによる中白の発生

4 段重ねの下から 3 段目の木枠に $600 \mathrm{~g} \pm 20 \mathrm{~g}$ の芋を充 填し, ゲージ圧 $0.8 \mathrm{kgf} / \mathrm{cm}^{2}$ と $1.1 \mathrm{kgf} / \mathrm{cm}^{2}$ の蒸気をボイ ラーから直接木枠に導入して蒸す方式およびゲージ圧 0.8 $\mathrm{kgf} / \mathrm{cm}^{2}$ の蒸気を釜の湯を通過させて導入する間接導入蒸 し方式（以下，湯通し蒸気とする）の 3 条件で蒸しあげ, この同じ実験を 3 回繰り返した。

中白の有無の確認は, 芋の中心温度が $98^{\circ} \mathrm{C}$ に到達してか ら 100 分後まで 10 分毎に芋を 3 個ずっ取り出し, 目視で 行った. 充分に蒸されたものは肉色が透き通った黄色に変 化するが， 中白の部分は白いままで光線が透らない状態に なる. 少しであ中白のあるものは「中白あり」と判定した.

(2) 芋の重量別蒸し時間と中白の発生

4 段重水の木枠に， $800 \pm 20 \mathrm{~g}, 600 \pm 20 \mathrm{~g}, 500 \pm 20 \mathrm{~g}, 400$ $\pm 20 \mathrm{~g}$ の芋を, 下の段から大きい順に充填し，ゲージ圧 0.8 $\mathrm{kgf} / \mathrm{cm}^{2}$ で湯通し蒸気を間接導入する蒸し方式で蒸しあげ た. 中白の確認は同様に行い, 実験を 3 回繰り返した.

(3) 湯通し蒸気導入方式による蒸しの実証試験

慣行法で原料を 3 段階に区分けし，4 段重ねの木枠に下 から 1 段目に $800 \mathrm{~g}$ 区，2段目と 3 段目に $600 \mathrm{~g}$ 区，4 段目 に $400 \mathrm{~g}$ 区の芋を充填し, ゲージ圧 $0.8 \mathrm{kgf} / \mathrm{cm}^{2}$ の蒸気を 湯通しする間接導入方式で蒸しあげ，その温度履歴を測定 し, 中白の有無を確認した。

\section{3. 温度測定}

木枠内および芋の中心温度は，Fig. 1 のように配置した 熱電対で連続的に測定した. 慣行法で区分けした原料構成

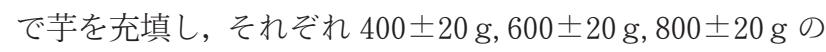
芋の中心温度を測定した。

\section{4. マルトース生成の適正加熱温度と時間}

生甘藷 5 個を剥皮し，それぞれから $10 \mathrm{~g}$ ずつ採取した 
Table 1 The effect of steaming time on white spot occurrence of sweet potatoes under various steam pressures

\begin{tabular}{|c|c|c|c|c|c|c|c|}
\hline \multirow{2}{*}{$\begin{array}{l}\text { Steam pressure } \\
\qquad\left(\mathrm{kgf} / \mathrm{cm}^{2}\right)\end{array}$} & \multicolumn{7}{|c|}{ Steaming time (min) } \\
\hline & 40 & 50 & 60 & 70 & 80 & 90 & 100 \\
\hline 0.8 & + & + & + & + & + & + & - \\
\hline 1.1 & + & + & + & + & + & - & - \\
\hline $\begin{array}{l}0.8 \\
\text { pass through hot water }\end{array}$ & + & + & + & - & - & - & - \\
\hline \multicolumn{8}{|c|}{$\begin{array}{l}+ \text {, white spot observed. } \\
- \text {, white spot disappeared. } \\
\text { Steaming time indicates the retention time of the center } \\
\text { temperature of sweet potato above } 98^{\circ} \mathrm{C} \text {. }\end{array}$} \\
\hline
\end{tabular}

合計 $50 \mathrm{~g}$ を蒸留水 $150 \mathrm{ml}$ とと屯に磨砕した。これをろ過 し pH 3.6 で 10 分間保持後, $4000 \mathrm{rpm}$ で 5 分間遠心分離 し, $3 \% \mathrm{NH}_{4} \mathrm{OH}$ で $\mathrm{pH} 4.8$ に調整し, $250 \mathrm{ml}$ に定容にして 粗䤉素液を得た。

この粗酵素液の原液㧍よび 5 倍, 25 倍の希釈液 $2 \mathrm{ml}$ を $0.6 \%$ 可溶性澱粉 $25 \mathrm{ml}, \mathrm{pH} 4.8$ 䣷酸緩衝液 $3 \mathrm{ml}$ の混合液に 加え, $40,50,60,70,80^{\circ} \mathrm{C}$ の恒温水槽で $5,15,30,60$ 分 間保持した後, $100^{\circ} \mathrm{C}$ で 10 分間加熱し酵素を失活させた.

この試料について Somogyi-Nelson 法により $520 \mathrm{~nm}$ で の吸光度を測定し, 乾物 $1 \mathrm{~g}$ 当たりの生成マルトース量 （mg/g-dry）を求めた.

\section{結果および考察}

\section{1. 蒸気の導入方式の違いによる中白発生}

芋を異なるゲージ圧の蒸気と, 異なる蒸気導入方式で蒸 しあげ，加熱時間と中白の発生との関係について検討した (Table 1). 一般的に行われている直接蒸気を蒸器に導入 する方式では, ゲージ圧 $0.8 \mathrm{kgf} / \mathrm{cm}^{2}$ と低い場合に中白が 発生しやすく, ゲージ圧を $1.1 \mathrm{kgf} / \mathrm{cm}^{2}$ に上げることによ り, 短時間で中白が消えた.また, ゲージ圧 $0.8 \mathrm{kgf} / \mathrm{cm}^{2} の$ 湯通し蒸気を用いた場合, $1.1 \mathrm{kgf} / \mathrm{cm}^{2}$ で蒸気を直接導入 する方式に比べ，蒸し時間を大幅に短縮できた.

\section{2. 芋の重量別蒸し時間と中白の発生}

湯通し蒸気による方式で芋を蒸しあげたとき, 芋の重量 別蒸し時間と中白の発生の関係を Table 2 に示した. 最も 小さな $400 \pm 20 \mathrm{~g}$ の芋は, 40 分では中白が残っていたが 50 分では中白は確認されなかった。 次いで $500 \pm 20 \mathrm{~g}$ の芋 は, 50 分では中白が残っていたが 60 分では確認されな かった。

$600 \pm 20 \mathrm{~g}$ の芋は, 60 分では中白が残っていたが 70 分 では確認されなかった，最む大きな $800 \pm 20 \mathrm{~g}$ の芋は, 70 分では中白が残っていたが 80 分では確認されなかった。 この結果によると, 中白の発生は芋の大きさと密接に関係 し, 中白の消失には芋重量のグラム数の $1 / 10$ 以上の加熱 時間を必要としている。
Table 2 The effect of steaming time on white spot occurrence of various weight sweet potatoes

\begin{tabular}{ccccccc}
\hline \hline Weight & \multicolumn{6}{c}{ Steaming time (min) } \\
\cline { 2 - 7 }$(\mathrm{g} /$ tuber $)$ & 40 & 50 & 60 & 70 & 80 & 90 \\
\hline $400 \pm 20$ & + & - & - & - & - & - \\
$500 \pm 20$ & + & + & - & - & - & - \\
$600 \pm 20$ & + & + & + & - & - & - \\
$800 \pm 20$ & + & + & + & + & - & - \\
\hline
\end{tabular}

+ , white spot observed.

- , white spot disappeared.

Steaming time indicates the period of the center temperature above $98^{\circ} \mathrm{C}$.

また，中白が消失した芋の細胞の顕微鏡写真 (Fig. 2) で は，生芋の細胞中に存在していた生澱粉粒は消失してお り，これからも中白の消失と生澱粉粒の消失が密接に関係 していることが示唆された。

このように，蒸切干し製造における蒸しは，40 分間の蒸 しでの芋組織の軟化 ${ }^{2)}, 95^{\circ} \mathrm{C} 10$ 分間の蒸しでの芋組織の澱 粉の糊化 ${ }^{3)}, 60$ 分間の焙焼での糊化之澱粉粒の消失 ${ }^{4)}$ など の場合と比較し, $98^{\circ} \mathrm{C}$ 以上で 50〜80 分以上という遙かに 高温長時間の過酷な加熱条件で蒸していることになる.

檜作 ${ }^{5)}$ らは， $5 \%$ 澱粉懸濁液を用い， $100^{\circ} \mathrm{C}$ で 5 分間之 30 分間加熱した後の老化速度を比較し, 凝集核となるむのが 消失するほど過酷な糊化条件下で加熱された糊液は, 温和 な糊化条件下で糊化した糊液よりも老化が遅くなることを 報告している．藤巻 ${ }^{6)}$ も，過酷な加熱により凝集核を消失 した糊液は，老化速度が遅いことを報告している．

蒸切干しの過酷な蒸し条件は, 長い経験から得られたも のであり，乾燥製品に一定の粘りや柔らかさを持たせる目 的あある。

\section{3. 湯通し蒸気導入方式による蒸しの実証試験}

湯通し蒸気導入方式で蒸しあげたときの芋の中心温度の 変化を Fig. 3 に示す。この図から芋の中心温度は $98^{\circ} \mathrm{C}$ 以 上で少なくとも 30 分間以上保持されていることが分かる. また，芋の外側の温度が $95^{\circ} \mathrm{C}$ に達してから中心温度が $100^{\circ} \mathrm{C}$ に達するまでに, $400 \pm 20 \mathrm{~g}$ の芋では 50 分, $600 \pm 20$ $\mathrm{g}$ の芋では 100 分, $800 \pm 20 \mathrm{~g}$ の芋では実に 140 分以上の 時間がかかっている.

\section{4. マルトース生成の適正加熱温度と時間}

甘藷に含まれる $\beta$-アミラーゼは比較的熱に強く, 生澱 粉には作用せず，糊化した澱粉に作用する ${ }^{4)}$. 単離した甘 藷澱粉の糊化開始温度は, 約 $65^{\circ} \mathrm{C}^{7)}, 65.8^{\circ} \mathrm{C}^{8)}$ 付近である が，澱粉粒毎に異なり，同一試料でも糊化し易い粒と糊化 し難い粒の間に約 $10^{\circ} \mathrm{C}$ の相違があることが示されている.

$16 \mu \mathrm{m}$ 内外の澱粉粒では糊化温度は $57.8 \sim 63.6{ }^{\circ} \mathrm{C}^{9)}$ であ り, 野田ら ${ }^{10)}$ は 51 種類の甘藷澱粉の糊化開始温度を測定 し， 55.7〜 73.1 ${ }^{\circ} \mathrm{C}$ の範囲であることを報告している. 一方, 


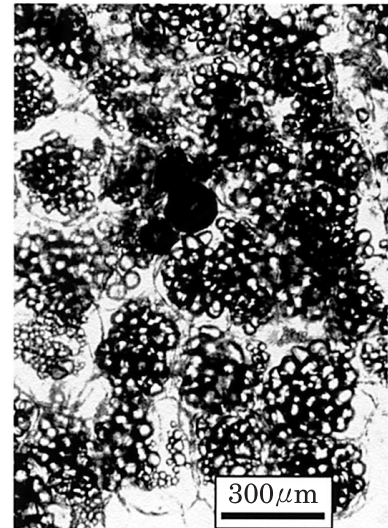

a. Raw tuber

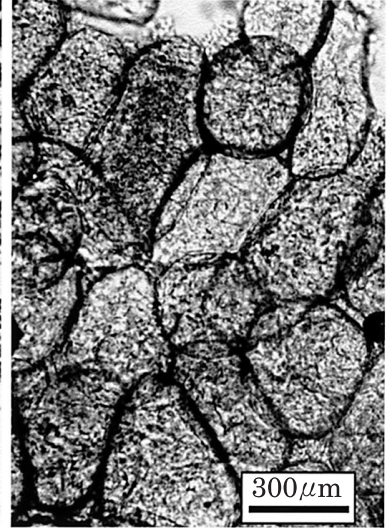

b. After steaming tuber

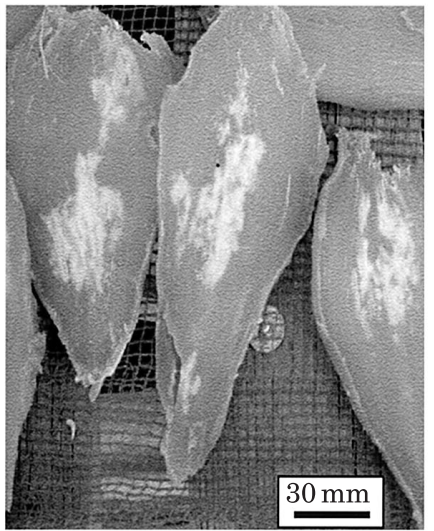

c. White spot with steamed sweet potato tuber

Fig. 2 The cell structure of sweet potato tuber and white spot with steamed sweet potato tuber

The microscopic photographs show the cell structure before and after steaming sweet potato tuber. a, Many starch granules gathered in the cells before steaming.

b, The raw starch granules cannot be seen in the cells in which the white spot disappeared after steaming.

本研究における甘藷組織中の澱粉の糊化開始温度は 59.0 $63.2^{\circ} \mathrm{C}$, 平均 $60.5^{\circ} \mathrm{C}$ であることが高橋らによって示されて

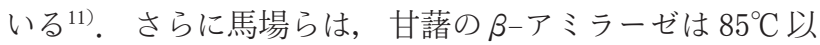
上で失活すると報告している ${ }^{12)}$ 。このことから，甘藷から 抽出した $\beta$-アミラーゼ粗酵素液を基質の可溶性澱粉に加 え, $40,50,60,70,80^{\circ} \mathrm{C}$ の温浴で $5,15,30,60$ 分間振 とう攪拌し，マルトースの生成量から酵素反応の最適温度 を検討した。 その結果は Fig. 4 に示した。 各反応時間にお いて $\beta$-アミラーゼは，40〜 $60^{\circ} \mathrm{C}$ の間で良好な活性を示し， $70^{\circ} \mathrm{C}$ になる活性が急激に低下し， $80^{\circ} \mathrm{C}$ で失活することが 確認された。

一方, 澱粉からマルトースへの変換を進めるには, 30 分 間程度 $40 \sim 60^{\circ} \mathrm{C}$ に保持することが必要と考えられた。

\section{5. 新しい蒸し加熱条件の制御方法の提案}

一般的な蒸し方式で甘藷を蒸す場合, アミラーゼの良好 な活性状態の温度範囲を長時間維持することは困難と考え られる。製造現場での実装置による蒸し工程において，芋 の中心温度が $40 \sim 60^{\circ} \mathrm{C}$ を通過する時間は, Fig. 3 に示す ように, 最む小さい 4 段目の $400 \pm 20 \mathrm{~g}$ の芋では約 10 分 間, 量的に最も多い 3 段目の $600 \pm 20 \mathrm{~g}$ の芋では 23 分間, 最下段の $800 \pm 20 \mathrm{~g}$ では 33 分間であった.

実際の蒸し工程では，甘藷は徐々に加熱され， $60^{\circ} \mathrm{C}$ 前後

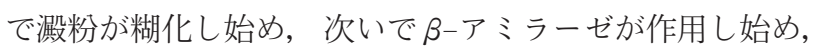
澱粉の糖化が進むと考えられる。このような变化は一様に 起こるのではなく，蒸気に触れた甘藷の表面から始まり， 徐々に内部へと浸透13) していく. Fig. 3 では，最も大きな $800 \mathrm{~g}$ 区の芋を充填している下から一段目の蒸器内の温度 は, 加熱開始後約 20 分で急激に上昇し始めるが, 芋の中心 温度はゆっくりと上昇し, $75^{\circ} \mathrm{C}$ に達するまでに 110 分以上 かかっている. 55〜 $75^{\circ} \mathrm{C}$ の温度域を通過する時間は約 35 分間であり， $600 \mathrm{~g}$ 区では 24 分間，最も小さい $400 \mathrm{~g}$ 区の

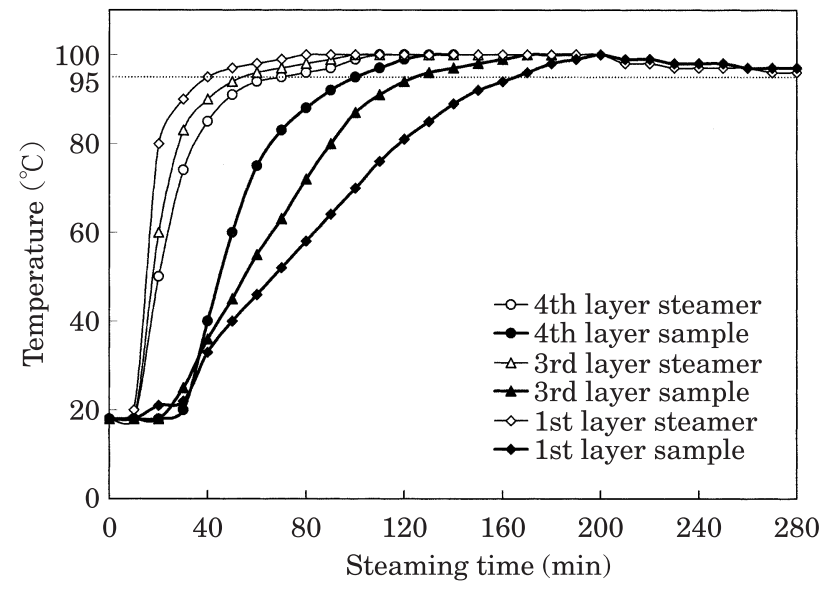

Fig. 3 Changes in center temperature of each sweet potato sample and steam temperature of each steamer

甘藷ではわずか 12 分間である。これらの結果から，これま での蒸し工程では, $400 \mathrm{~g}$ 区の芋では, 必ずしも充分なマル トースの蓄積効果が得られていないことが示唆された.

全体の芋がマルトースを充分に生成するには， $55 \sim 75^{\circ} \mathrm{C}$ の温度域を通過する時間を少なくとも 30 分間，できれば それ以上の長い時間を確保できる加熱法が期待される.

一番上段の蒸器に充填した最む小さな $400 \mathrm{~g}$ 区の芋を指 標に, $55 \sim 75^{\circ} \mathrm{C}$ の温度域を 30 分間かけて通過させること と, 温度上昇が始まってから 50 分後に $75^{\circ} \mathrm{C}$ に達するよう に改善する方策を考察した。すなわち，温度モニターを用 い，湯通し蒸気を間接導入して蒸す新しい方式で蒸しあげ る方法を取り入れ, 蒸気が 4 段目の蒸器に達し, 蒸器内温 度が $90^{\circ} \mathrm{C}$ 以上になり，芋の中心温度が $55^{\circ} \mathrm{C}$ を示した時点 で，ボイラーからの蒸気圧を一旦下げ，30 分間程度その温 度状態を維持する。その後，ゲージ圧を $0.8 \mathrm{kgf} / \mathrm{cm}^{2}$ に上 


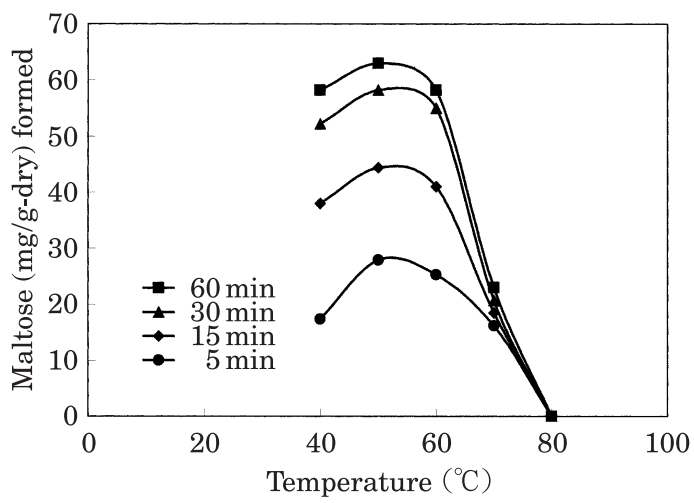

Fig. 4 Optimum temperature and reaction time of maltose formation using $\beta$-amylase of sweet potato

げ， $98^{\circ} \mathrm{C}$ 以上の蒸し温度に回復させる.

このようにした場合， $400 \mathrm{~g}$ 区の芋の中心温度が $75^{\circ} \mathrm{C}$ に 達したとき, $600 \mathrm{~g}$ 区之 $800 \mathrm{~g}$ 区の芋の中心温度は, やっと $55^{\circ} \mathrm{C}$ に達した状態と考えられる。しかし，ゲージ圧を元の $0.8 \mathrm{kgf} / \mathrm{cm}^{2}$ に戻したときの $55^{\circ} \mathrm{C}$ から $75^{\circ} \mathrm{C}$ までの温度の 上昇は, $600 \mathrm{~g}$ 区の芋で約 24 分, $800 \mathrm{~g}$ 区では 35 分であ り, 急速な温度上昇がすぐには始まらないことを考える と, いずれあ $「 55^{\circ} \mathrm{C}$ から $75^{\circ} \mathrm{C}$ の温度域での 30 分以上の加 熱」(14) という条件を満足すると考えられる。

原料の泉 13 号では, 生の状態のマルトース換算還元糖 は $24.9 \mathrm{mg} / \mathrm{g}$ であるが, $25 \mathrm{~g}$ の甘藷切片をラップしこれを アルミ箔で包み, 雾囲気温度 $60^{\circ} \mathrm{C}$ で 90 分蒸した後には $94.0 \mathrm{mg} / \mathrm{g}$ に増加し, $70^{\circ} \mathrm{C}$ で 90 分蒸した後には $159.8 \mathrm{mg} /$ $\mathrm{g}$ と大幅に増加し, 加熱に伴うアミラーゼの作用が確認さ れた。

\section{6. 中白消失と甘味生成における成分間反応の考察}

並木ら ${ }^{15)}$ は, 澱粉を主体とする食品では, 水分保持性, 硬さ，粘り，食味等の向上には，澱粉の機能である成分間 反応が重要な役割を果たしていると述べている。

蒸し工程における中白の消失と甘味およびゲル性等の生 成に関する成分間反応は，以下のように考えられる。

(1) 生甘藷の細胞内に複粒の形で存在する潵粉粒内のア ミロースとアミロペクチンは, $60^{\circ} \mathrm{C}$ 前後で加熱されると測 粉成分の部分的な溶出之糊化が起こり, $\beta$-アミラーゼで加 水分解されやすくなる。 (2) 中間の温度で維持されるとマル トースの生成之 ${ }^{15}$ 澱粉粒の膨潤が進み ${ }^{177} 18$, (3) $98^{\circ} \mathrm{C}$ 以上で 長時間の過酷な加熱により, 水分子が測粉の微結晶の中ま で入り込み ${ }^{8)}$ ，澱粉の結晶構造を完全に破壊するとともに， 細胞内全体に充満する ${ }^{19}$. この時点で中白は消失している とみられる. (4)水分子はアミロペクチンの分子間に入り込 み, 結合水の形で安定する ${ }^{20)}$. この状態は, 放冷後ゲル化 して安定なままで維持されると考えられる。

今後, 老化しにくく品質的にも優れた甘藷蒸切干し製品 を製造する場合には，完全蒸煮に近い効果的な蒸煮条件が
必要になると考えられる。

$$
\text { 要 約 }
$$

甘藷蒸切干しは日本の伝統食品であるが, 輸入品が増加 する中で, さらなる品質向上が求められている.

近年, その製造過程で, 蒸し後に芋の中心部分が白く残 る中白（なかじろ）という現象がみられるようになってい る.この問題を解決するため, ボイラーのゲージ圧を通常 の $0.8 \mathrm{kgf} / \mathrm{cm}^{2}$ から $1.1 \mathrm{kgf} / \mathrm{cm}^{2}$ に上げた蒸気を蒸器に導 入することにより，甘藷の蒸し工程で短時間に中白が消失 することを確認した。 また，ゲージ圧 $0.8 \mathrm{kgf} / \mathrm{cm}^{2}$ の蒸気 であっても釜の中の湯を通過させてから導入することで中 白の発生を抑え, 蒸し時間を短縮できることを明らかにし た。

さらに，蒸し工程において現在よりゆっくり温度を上昇 させ，充分加熱することにより，澱粉の糖化を促進し，老 化しにくい甘みの優れた製品にする蒸し制御技術について 考察し, 新しい蒸し技術を開発した.

甘藷蒸切干しの製造法について，これまで伝統的な経験 之勘に頼っていた技術を数值化し，これを中白の発生防止 に結びっけるとともに，付加価値の高い甘藷蒸切干しの製 造技術を確立することができた。

\section{文献}

1）鈴木金苗, カンショの品種について,「スイカ・カンショ作 の展望と栽培技術」，（静岡県海岸砂地農業振興協儀会技術 研究会資料，静岡）p. 12（1980）.

2） 中嶋昭雄, 蒸し切り干しいあの製造に関する研究 (第 1 報) 白粉中の糖類と生成条件について，日食工誌，17，431-436 (1970).

3）久保田清，細川嘉彦，鈴木寛一，保坂秀明，New Food Industry, 21, 44-45 (1979).

4) 桐㴊壽子, 久保田紀久枝, 甘藷の加熱調理に関する研究 (第 1 報）生成糖と $\beta$-アミラーゼ活性，家政誌， $27 ， 418-422$ (1976).

5） 檜作 進, 伊藤恵子, 前田 㦑, 二国二郎, 溉粉科学, 19 , 70 (1972).

6）藤巻正生，炭水化物，「食糧保蔵学」，第 2 版，(朝倉書店, 東京), pp. 119-120 (1983).

7）竹田知恵乃, 檜作 進, 農化, 48, 663, (1974).

8）二國二郎，中村 徳，鈴木繁男，泼粉と水，「溉粉科学ハン ドブック」, 第 1 版, (朝倉書店, 東京), pp. 36-41（1977）.

9）神立 誠, イモ類,「三訂, 食品化学」, 第 9 版, (光生館, 東京), pp. 122-123 (1974).

10）野田高弘, 高畑康浩, 須田郁夫, 佐藤哲生, 石黒浩二, 山川 理，カンショ測粉特性とアミロペクチン鎖長分布との関連 性, 九農研，63，37，(1998).

11） 高橋浩司, 白井邦郎, 和田敬三, 川村 亮, 示差熱分析によ る食品中澱粉の熱的性質の検討, 農化, 52, 441-448 (1978).

12）馬場 透, スィートポテトチップの着色に関する要因,「甘 藷の高度利用に関する研究, 学位論文」p. 28（1988）.

13）桐㴊壽子, 桐㴊滋雄, 甘藷の加熱調理に関する研究（第 2 報）走查電子顕微鏡による観察，家政誌，27，423-426 (1976). 
14）藤巻正生, 金田尚志, 秦 忠夫, 柴崎一雄, 不破英次, 稲垣 長典, 坂村貞雄, 稲神 馨, 門田 元, 松本 博, 植物性食 品の化学,「食品化学」, 第 7 版, (朝倉書店, 東京), p. 205 (1973).

15）並木満夫, 松下雪郎, 食品の物性, 「食品の品質之成分間反 応」，(講談社，東京）, p. 129 (1990).

16）坂村貞雄, 檜作 進, 野田万次郎, 藤巻正生, 小田切敏, 中 林敏郎, 炭水化物資源の利用, 「農産物利用学」, 第 3 版, (朝倉書店，東京)，p. 12 (1955).

17）桜井芳人, 満田久輝, 柴崎一雄, デンプンの老化, 「食品保
蔵」，第 8 版，(朝倉書店，東京)，p. 366 (1972).

18）森田義郎, 阿部義郎, 篠原 功, 炭水化物食品, 「有機工業 化学」, (培風館, 東京), pp. 335（1985）.

19）曽根敏麿, 各食品の粘調性,「食品の粘調性」, (光琳全書, 東京), pp. 63-66 (1966).

20）宮川金二郎，豊沢 功，大森正司，堀口恵子，食品の主な成 分,「フードサイエンス一新しい食品学総論」, 第 1 版, (化 学同人, 京都), p. 26 (1997).

(平成 16 年 8 月 25 日受付，平成 17 年 1 月 25 日受理) 